\title{
RESEARCH ON THE CLASSIFICATION OF LIFE-CYCLE SAFETY MONITORING LEVELS OF SUBSEA TUNNELS
}

\author{
Junfu LU, A/Prof. Dr. \\ Xiaoqiang XUE, M.S. \\ State Key Laboratory of Geohazard Prevention and Geoenvironment Protection, \\ Chengdu University of Technology
}

\begin{abstract}
As a traffic engineering project across straits or gulfs, subsea tunnel is one of the oceaneering with great construction difficulties, and the key to the success of subsea tunnel engineering lies in timely and accurate assessment of the structure safety of subsea tunnel engineering construction and life-cycle. Xiang'an Xiamen subsea tunnel is China's first subsea tunnel which crosses complex formation conditions, engineering accidents such as collapse, sudden inflow of water or mud might occur during tunnel construction and operation. Therefore, the concept of subsea tunnel life-cycle monitoring is proposed aiming at the particularity of subsea tunnels. The variation forms of subsea tunnel mainly include large deformation, collapse, primary support cracking, water leakage, water pressure increase, steel arch corrosion, concrete corrosion, longitudinal differential settlement, etc., and classification of the life-cycle safety monitoring levels of the subsea tunnel is conducted based on risk assessment theory and risk level management benchmark to determine the possible variation forms in the monitoring level segments. The research results will provide reference for the subsea tunnel life-cycle monitoring, disaster warning as well as risk management under construction or to be built at home and abroad.
\end{abstract}

Keywords: Subsea tunnel; Life-cycle; Safety monitoring; Monitoring level; Disaster warning

\section{INTRODUCTION}

The life-cycle period of engineering structure mainly includes selection of construction scheme, structure design, construction, operation, aging and abolishment. In recent years, the concept of engineering structure life-cycle is gradually adopted by engineering scholars. American Institute of Architects (1977) proposed the initial concept and thought, research risks and analysis methods of life-cycle economic analysis[1]. Flanagan (1984) made an in-depth discussion of the technical requirements, reasonable cost and other issues involved in life-cycle period cost management starting from the angle of architectural economics[2]. Frangopol (1999) proposed a cost-benefit bridge method combining life cycle reliability and life cycle cost[3]. At present, domestic and foreign researches on project life-cycle are mainly focused on life-cycle cost as well as life-cycle design and life-cycle management of bridge engineering, researches on life-cycle of subsea tunnel engineering are rarely seen, and the concept of life-cycle is merely introduced in tunnel risk analysis $[4,5]$.

In recent years, research on long-term safety monitoring of major projects has attracted more and more widespread attention in engineering circle, long-term safety monitoring system has been effectively implemented in the safety monitoring of long-span bridges in the United States, Canada, Europe, Japan, South Korea and other countries[6,7,8,9,10,11]. For example, long-term structural safety monitoring system has been installed on Confederation Bridge in Canada[12], Commodore Barry Bridge in the US[13], Akashi Kaikyo Bridge in Japan[14], Seohae Bridge in South Korea[15]. In China, structural safety monitoring and working condition assessment system has been installed on Tsing Ma Bridge in 
Hong Kong[16], Nanjing Yangtze River Bridge[17] and Wuhu Yangtze River Bridge[18], etc., providing a scientific decisionmaking basis for the management and maintenance of bridges. However, there is less research on long-term structural safety monitoring system for subsea tunnel engineering.

Since subsea tunnels cross stratums with complex geological conditions and high hydraulic pressure, material performance degradation caused by seawater corrosion, earthquakes and other factors will seriously imperil the safety of subsea tunnels. In case structural damage occurs during tunnel operations, it can easily lead to collapse, sudden inflow of water or mud and other disasters, causing disastrous consequences to the lives and property security of human. Therefore, it is of very important practical engineering significance to ensure the safety and durability of tunnels by establishing life-cycle safety monitoring levels of tunnel structure, real-time monitoring of the safety performance and stress state during tunnel construction, operation and aging maintenance phases as well as health diagnosis and safety assessment.

As China's first subsea tunnel, Xiang'an Xiamen subsea tunnel crosses multiple tectonic fracture zones at different positions, the fracture zones are composed of fully-heavily weathered granite with low rock mass strength and poor self-stability that are prone to seepage failure and other disasters. Thereby, we introduced project life-cycle concept in subsea tunnel monitoring and carried out research on the classification of life-cycle safety monitoring levels of the subsea tunnel by taking Xiang'an subsea tunnel engineering as the research object, the research results will provide valuable reference to similar projects at home and abroad.

\section{RESEARCH BACKGROUND}

Located in the northeast part of Xiamen Island, Xiang'an Xiamen subsea tunnel is a high-level highway and city fast track connecting Xiamen Island and the continental shelf of Xiang'an District, see the location map of Xiang'an Xiamen subsea tunnel in Fig. 1.

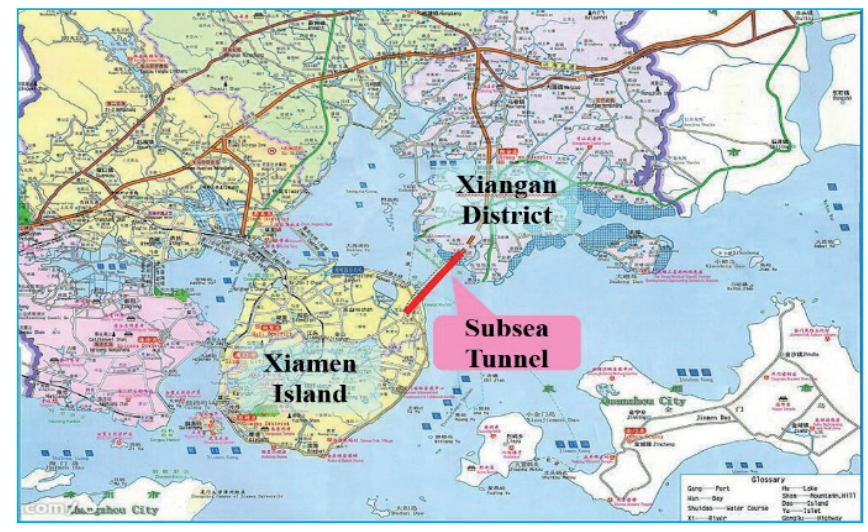

Fig. 1. Schematic diagram of proect location

With a total tunnel length of about $6.05 \mathrm{~km}$, Xiamen subsea tunnel is designed in a 3 -tunnel pattern, both sides are the main vehicle cross passageways, the middle is a tunnel for service; wherein the left and right main vehicle cross passageways adopt 6 two-way lanes with design driving speed of $80 \mathrm{~km} / \mathrm{h}$, the clear height of construction clearance is $5.0 \mathrm{~m}$, net width is $13.5 \mathrm{~m}$, and the distance between center lines of the main vehicle cross passageways is $52 \mathrm{~m}$, see Fig. 2 . There are 2 ventilation shafts, 5 transverse vehicle cross passageways and 12 transverse pedestrian cross passageways along the tunnel. Since Xiang'an subsea tunnel is located in national rare marine life protection zones of Chinese white dolphins and Xiamen amphioxus, the construction scheme of underground subsea tunnel excavation is eventually adopted upon considering marine life protection, port resource protection, geological conditions, engineering technology and cost, natural landscape and other factors.

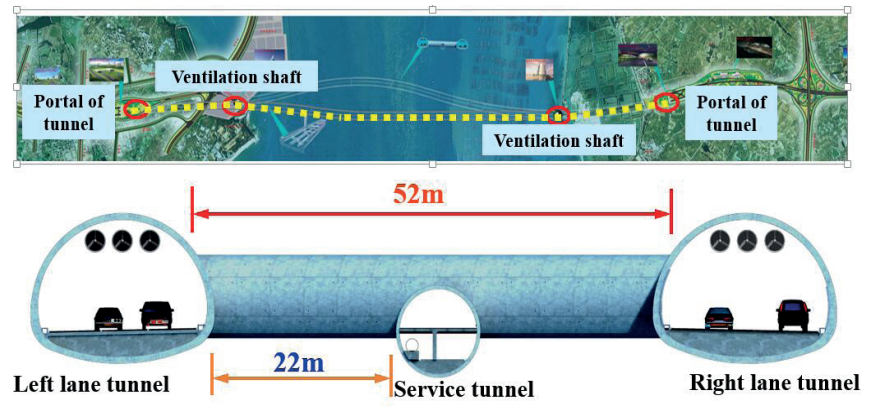

Fig. 2. Schematic diagram of the cross-section of tunnel layout

On account of being the first subsea tunnel on Chinese mainland, the following keys and difficult points were encountered during tunnel construction.

1) Extra large cross-section of tunnel excavation

The main passageway of Xiang'an subsea tunnel adopts a 3-lane highway tunnel, with clear height of construction clearance of $5.0 \mathrm{~m}$ and net width of $13.5 \mathrm{~m}$. The maximum excavation span is $16.84 \mathrm{~m}$, the largest excavation height is $12.26 \mathrm{~m}$, and the largest cross-section of tunnel excavation volume reaches $170 \mathrm{~m}^{2}$.

2) Land and shoal segment crosses a long distance of fullyheavily weathered granite

Xiang'an subsea tunnel mainly crosses fully-heavily weathered granite strata in land and shoal segment, with a total length of $6,244 \mathrm{~m}$, high underground water level and certain hydraulic pressure. Tunnel depth is shallow, which is generally $4-42 \mathrm{~m}$.

3) Seabed segment crosses weakly weathered bladder trough

Xiang'an subsea tunnel mainly crosses F1, F2 and F3 fully-heavily weathered deep troughs and F4 fully-heavily weathered deep bladder, with a total length of $1,121 \mathrm{~m}$, general depth of 21-53.7 $\mathrm{m}$ and water depth of 7.8-26.2 $\mathrm{m}$.

4) Crossing a wide range of sand layer

Xiang'an tunnel crosses a sand layer in Xiang'an end, with a total length of $1,721.5 \mathrm{~m}$ and general depth from the tunnel vault of 9-36.94 m.

5) Supporting system requires high durability

The design life of Xiang'an tunnel is 100 years, considering primary support, secondary lining as well as waterproof 
and drainage system in seawater environment require higher durability, therefore higher concrete durability is required for secondary lining. The level of concrete strength used for structural design shall not be lower than C45, seepage resistance level shall reach $\mathrm{P} 12$, and $90 \mathrm{~d}$ chloride diffusion coefficient shall be less than $2.0 \times 10^{-12} \mathrm{~m}^{2} / \mathrm{s}$ as required by construction requirements.

\section{ANALYSIS OF SUPPORTING STRUCTURE VARIATION FORMS IN SUBSEA TUNNELS}

Collapse, large deformation, supporting structure corrosion, primary support cracking, water leakage and other variations appeared in the construction process of Xiang'an subsea tunnel, we obtained factors that influence the safety of tunnel structure through an investigation of these variations. 1) Large deformation

Xiang'an tunnel crosses completely weathered granite, multiple weathered deep troughs, water-rich sand layer and weak surrounding rock segments that have obvious rheological properties, resulting in large deformation of the supporting structure during tunnel construction, and the surrounding rock deformation will be developed due to the "time effect". Upon conducting secondary lining supporting, surrounding rock deformation will also increase over a long period of time.

According to the displacement monitoring results in site construction phase, see the relations of data and reserved deformation in primary support monitoring cross-section that is sandy clay super shallow land segment with left tunnel in Fig. 3.

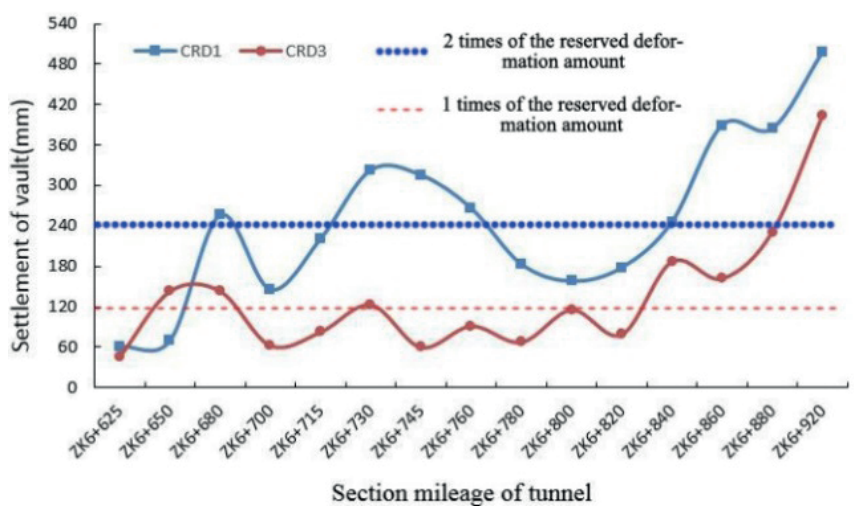

Fig. 3. Settling volume of sandy clay super shallow buried monitoring crosssection in the left tunnel

AS seen from Fig. 3, the maximum settling volume of the primary support CRD1 vault in sandy clay super shallow buried land segment is about $480.9 \mathrm{~mm}$, and the minimum settling volume is about $62 \mathrm{~mm}$, part of the segments occur large deformation that is greater than 2 times of the reserved deformation amount, causing variations of the supporting structure. Since the surrounding rock and supporting structure occur large deformation, severe consequences caused therefrom are shown in Fig. 4, such as the intrusion of surrounding rock in tunnel lining clearance limit, concrete cracking or peeling, steel support distortion, etc., seriously affecting construction safety, lining quality and construction period of the tunnel.

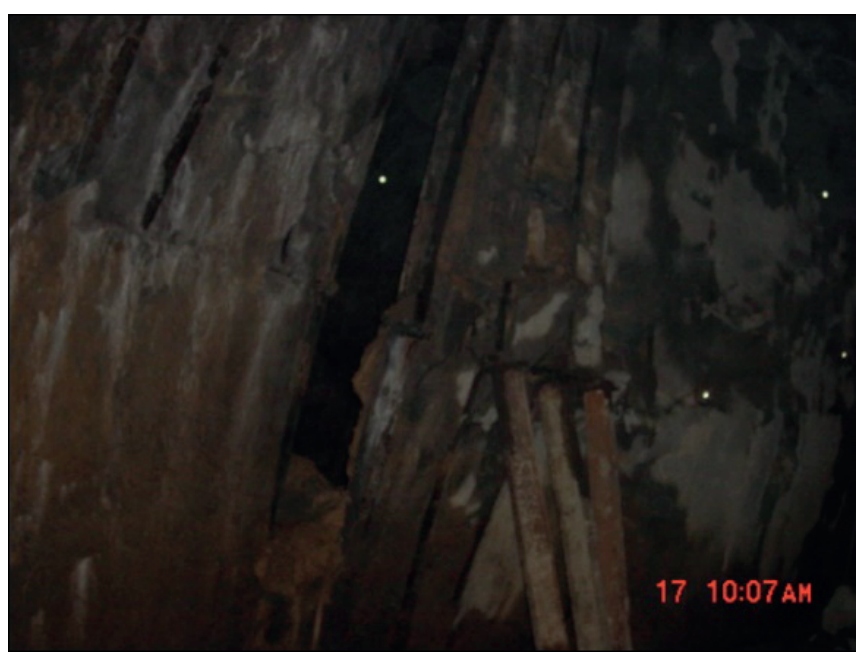

Fig. 4. Concrete peeling and steel arch distortion of primary support in subsea tunnels

\section{2) Collapse}

Subsea tunnel structure collapse will cause voids behind the lining and changes in the stress field of surrounding rock, upon conducting backfilling of the collapsing segments, the surrounding rock on tunnel crown will form loose pressure, which can cause severe stress abnormalities in lining structure, and a strong impact on the long-term safety performance of structure. During tunnel construction, collapse incidents occurred many times, see Fig. 5.

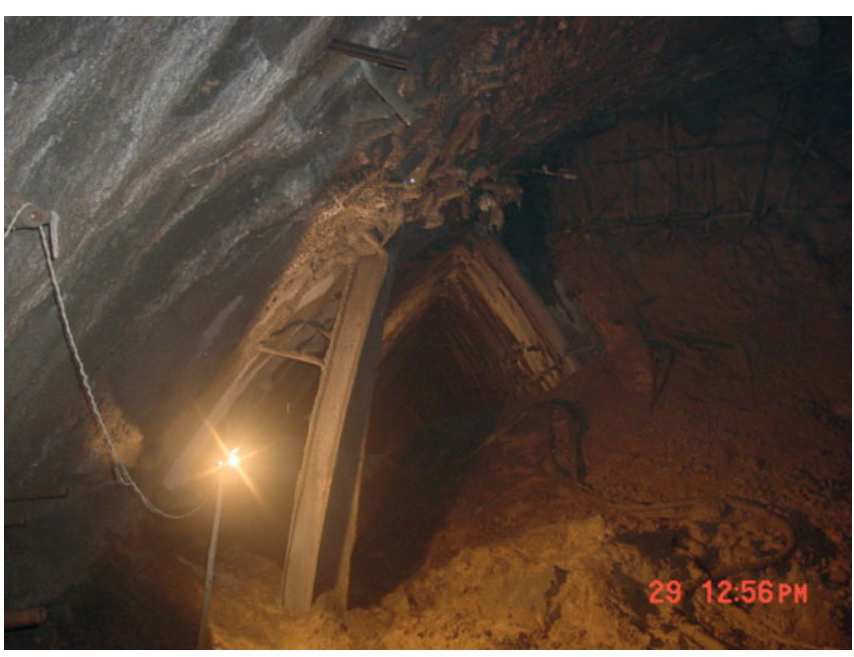

Fig. 5. Intrusion of surrounding rock and primary support in clearance limit of subsea tunnel

3) Primary support cracking and water leakage of tunnel

Water leakage of the structure will affect the durability of structural materials, in particular, under the special hydrological and geological environment between the sea and tidal tunnel segments, seawater corrosion on tunnel 
structure can not be ignored, lining cracking and water leakage will seriously affect the life of tunnel structure. The primary support cracking and water seepage on Xiang'an Xiamen subsea tunnel site are as shown in Fig. 6.

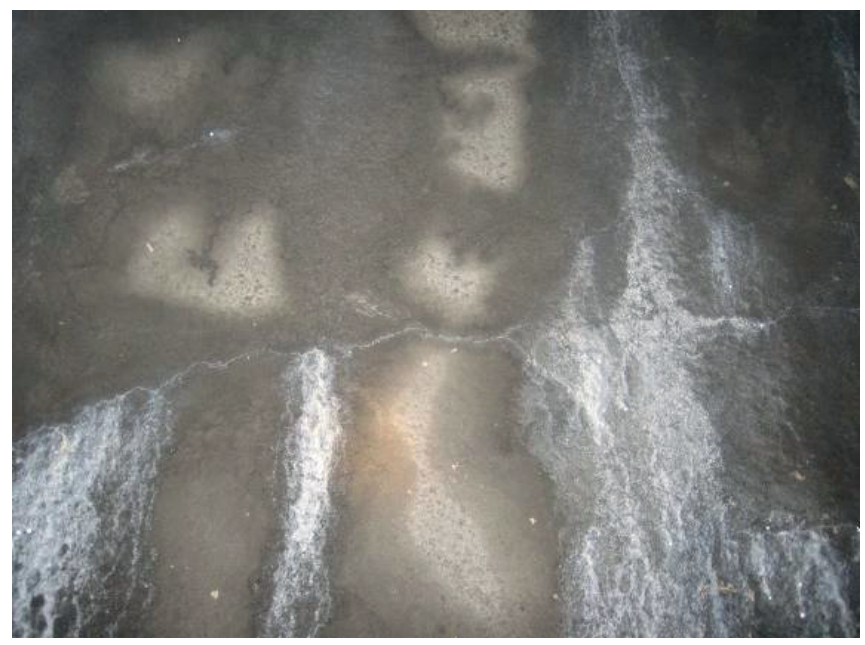

(a) Cracking and water seepage of primary support

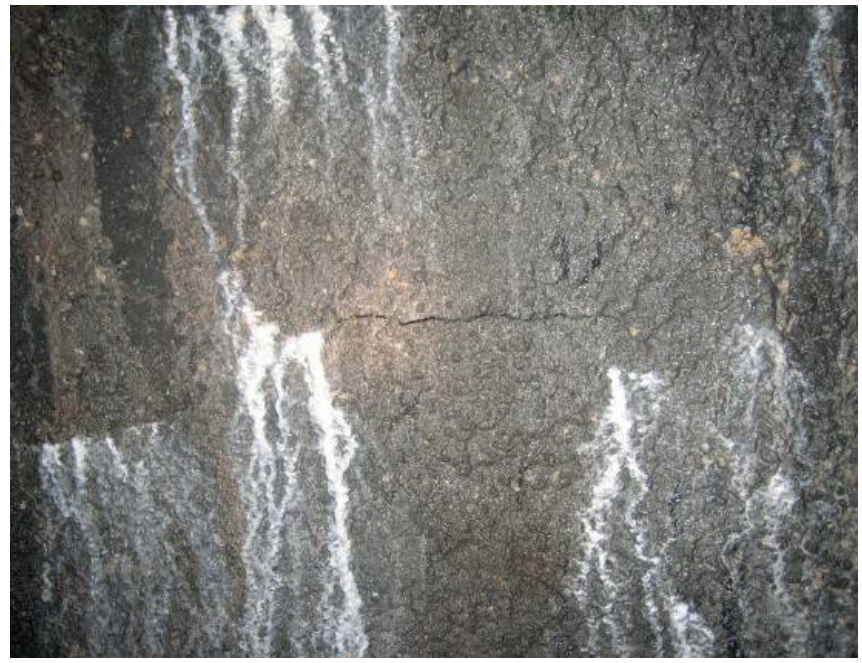

(b) Cracking and water seepage of primary support

Fig.6. Schematic diagram of cracking and water seepage of primary support on site

\section{4) Water pressure increase}

The total head of the seawater is $50-65 \mathrm{~m}$ and the maximum hydrostatic pressure of the crown is $0.65 \mathrm{MPa}$ in the ground where Xiang'an tunnel crosses, since the subsea tunnel is located under the underwater rock, its top seawater can be infinitely supplied. With the passage of time, due to the serious corrosion of seawater on grouting water shutoff materials and advanced support, the permeability coefficient of surrounding rock around the tunnel will increase and infiltration volume will also gradually increase. On account of the limited emission principle, water pressure will gradually increase and eventually reach the maximum water pressure in case the drainage system is blocked by silt, thus posing a strong impact on the long-term safety of tunnel structure.
See the water plugging effect before and after whole crosssection grouting of Xiang'an tunnel F1 weathered trough segment in Fig. 7.

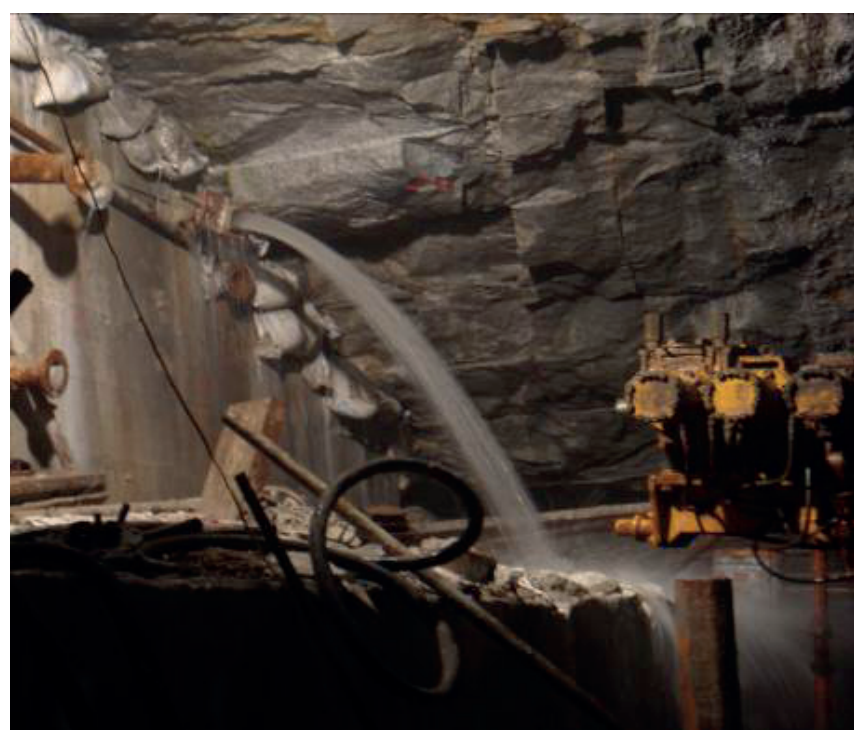

(a) Large amount of water in tunnel before grouting

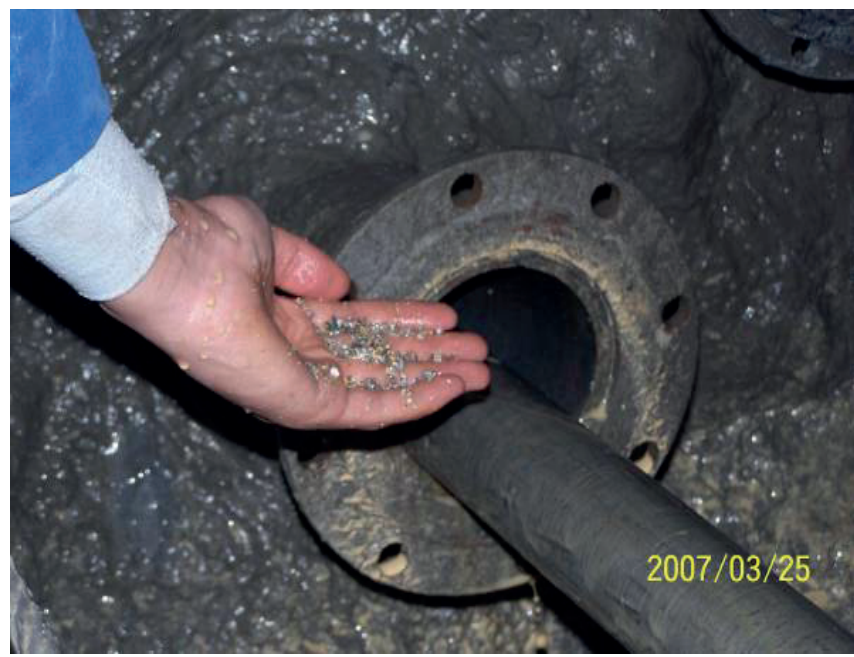

(b) Tunnel water disappeared after grouting

Fig.7. Grouting and water plugging at whole cross-section of F1 weathered trough

5) Steel corrosion of primary support and advanced support

Compared with general tunnels, the biggest characteristic of subsea tunnel is the corrosion of seawater on supporting structure. Primary support corrosion results from the intrusion of electrochemical ions and chloride ions as well as concrete carbonization, the corrosion rate in lining cracking and water leakage area increases since the steel support or advanced support are directly exposed in seawater, in addition, concrete cracking occurs due to corrosion expansion, severely reducing the material strength of primary support and advanced support, eventually resulting in the loss of bearing capacity. Serious corrosion of primary support was found in field research, which is mainly in sea area segment, 
especially in weathered bladder trough, corrosion situation is shown in Fig. 8.

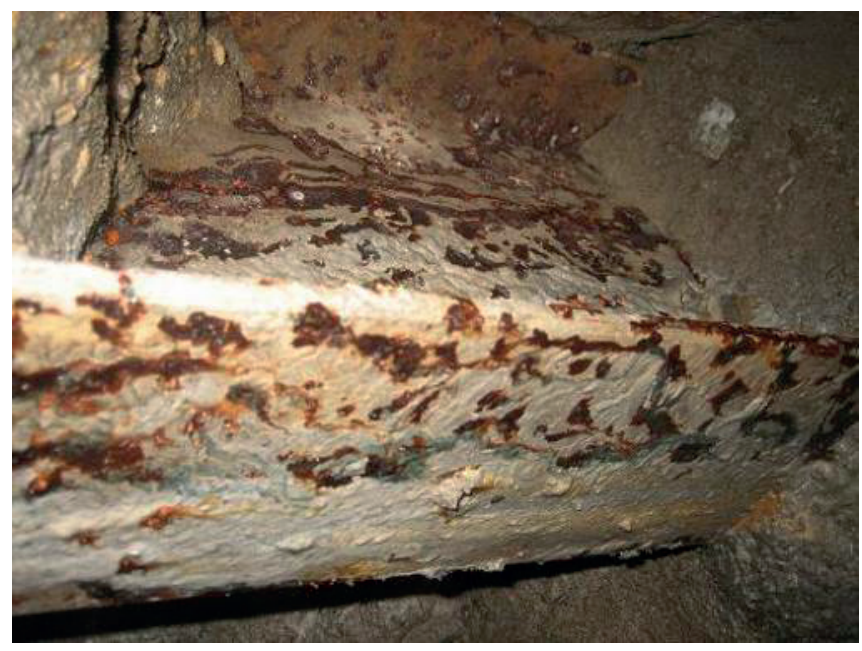

Fig. 8. Steel corrosion in primary support of subsea tunnel

\section{RESULTS AND DISCUSSION}

\section{CLASSIFICATION OF SUBSEA TUNNEL SAFETY MONITORING LEVELS BASED ON RISK LEVEL STANDARD}

Classification of subsea tunnel safety monitoring levels based on risk level standard

At present, the safety monitoring level of subsea tunnels is mainly determined as per the classification of surrounding rock, however, tunnel risks are not only related to the level of surrounding rock, but also the buried depth of tunnel, construction method, management level of the construction unit and other factors, risk analysis theory is introduced to establish the life-cycle safety monitoring levels of tunnels.

\section{Determination method of risk level}

The measurement of risk requires indexes, and the current commonly used international risk rating method mainly measures via the product of risk occurrence probability and risk consequences [19], see formula (1).

$$
R=P \times C
$$

Where:

$R$ - risk level;

$P$ - risk occurrence probability;

$C$ - risk consequences.

Classification of risk probability levels and risk consequence levels

Since risk is mainly determined via the product of risk probability and risk consequences, hence risk level is jointly determined by risk probability level and risk consequence level, and level classification is required.

1) Classification of risk probability levels

There are many uncertain factors in the probability of risk accident occurrence during construction, the occurrence time, location, form and scale are all undetermined, probability or probability level are used to describe the uncertain events in mathematics. Risk events are classified into five levels according to the different probability, and the risk probability of uncertain factors is converted into risk probability index to facilitate quantitative analysis, see Table. 1.

Tab. 1. Probability Level Standard

\begin{tabular}{|c|c|c|c|}
\hline $\begin{array}{c}\text { Probability } \\
\text { range }\end{array}$ & $\begin{array}{c}\text { Center } \\
\text { value }\end{array}$ & $\begin{array}{c}\text { Probability level } \\
\text { description }\end{array}$ & $\begin{array}{c}\text { Probability } \\
\text { index }\end{array}$ \\
\hline$>0.3$ & 1 & Frequently occurs & 5 \\
\hline $0.03-0.3$ & 0.1 & Probably & 4 \\
\hline $0.003-0.03$ & 0.01 & Accidentally & 3 \\
\hline $0.0003-0.003$ & 0.001 & Rarely occurs & 2 \\
\hline$<0.0003$ & 0.0001 & Impossible & 1 \\
\hline
\end{tabular}

2) Classification of risk consequence levels

Different assessment levels of consequence levels are adopted according to different risk consequences, but the losses or adverse consequences caused by the accident under the same level are divided into 5 levels, uncertain factors that might cause risk consequences are converted into consequence index to facilitate quantitative analysis, see Table. 2 .

Tab. 2. Classification of risk consequences

\begin{tabular}{|l|c|c|}
\hline \multicolumn{1}{|c|}{ Event definition } & $\begin{array}{c}\text { Consequence } \\
\text { description }\end{array}$ & $\begin{array}{c}\text { Consequence } \\
\text { index }\end{array}$ \\
\hline $\begin{array}{l}\text { A large area of damage, the whole } \\
\text { or part needs to be rebuilt; serious } \\
\text { environmental damage; casualties. }\end{array}$ & $\begin{array}{c}\text { Disastrous } \\
\text { consequences }\end{array}$ & 5 \\
\hline $\begin{array}{l}\text { Endangering the main project; } \\
\text { a lot of repair work is required, } \\
\text { environment is damaged, traffic } \\
\text { roads are blocked; personnel are } \\
\text { injured. }\end{array}$ & $\begin{array}{c}\text { Serious } \\
\text { consequences }\end{array}$ & 4 \\
\hline $\begin{array}{l}\text { Emergency handling is required, } \\
\text { property damage, delays in } \\
\text { construction, interference in } \\
\text { services; minor injuries. }\end{array}$ & $\begin{array}{c}\text { Less } \\
\text { consequences }\end{array}$ & 3 \\
\hline $\begin{array}{l}\text { Emergency handling is not required, } \\
\text { the loss is small; service is not } \\
\text { disturbed; personnel are slightly } \\
\text { injured. }\end{array}$ & $\begin{array}{c}\text { Light } \\
\text { consequences }\end{array}$ & 2 \\
\hline Slight effect. & $\begin{array}{l}\text { Consequences } \\
\text { can be ignored }\end{array}$ & 1 \\
\hline
\end{tabular}

Risk level standard

ALARP (As Low As Reasonably Practicable) is the most commonly used risk acceptance criteria, also known as the lowest feasible criterion, which means any engineering activity has risks that can not be eliminated via preventive measures, instead, balance between the risk level and interests must be made, see Fig. 9. In Fig. 9, risks are divided into three regions, if the assessed risk level is in an unacceptable 
region, it must be rejected or reduced by taking mandatory measures; if the risk level is in an acceptable risk region, there is no need to take any corresponding measures since the risk level is very low; if the risk level is in the maximum feasible reduction region, the effects after the implementation of various risk level reduction measures need to be examined and a contrast analysis shall be made to determine whether the risk is acceptable.

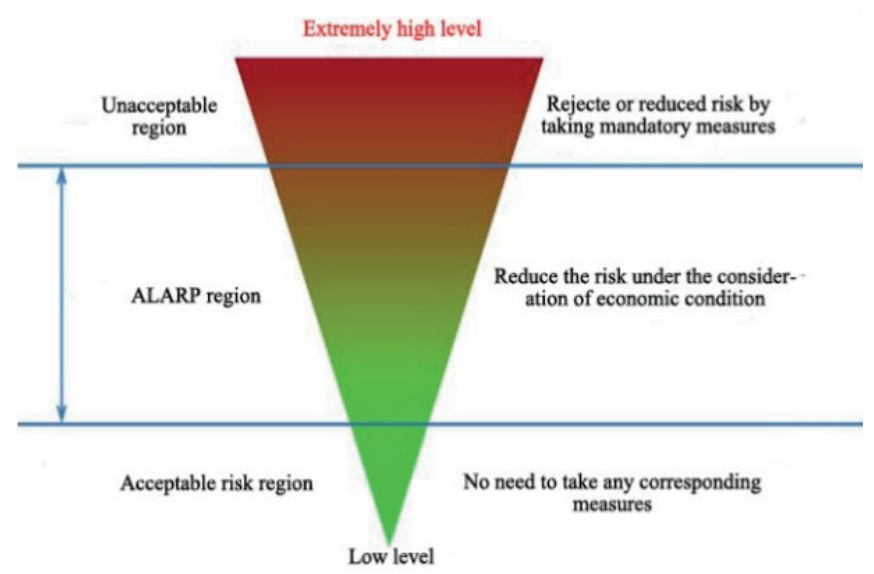

Fig. 9. ALARP risk management criteria

Based on ALARP criteria, the probability of accidents and the corresponding consequences are placed in a risk matrix, which is shown in Table. 3 .

\section{Classification of life-cycle safety monitoring levels}

In the actual tunnel engineering, the importance degree of safety monitoring of tunnel segments is related to the risk occurrence probability and risk consequences of the segments, sometimes the risk probability is big but the consequences are light, in this case monitoring can be lessened; however, sometimes the risk probability is less but the consequences are disastrous, in this case monitoring shall be strengthened; hence the importance degree of life-cycle safety monitoring can be determined as per the monitoring level.
Based on the determination method of risk level and aiming at the particularity of subsea tunnel engineering, life-cycle safety monitoring level is mainly assessed according to the product of risk probability index and risk consequence index of the tunnel, see formula (2).

$$
M=P_{1} \times C_{1}
$$

Where, $M$ - life-cycle safety monitoring level index; $P_{1}-$ risk probability index of the tunnel; $C_{1}$ - risk consequence index of the tunnel.

Based on the risk level management standard and the assessment method of monitoring level index, see Table. 4 , the life-cycle monitoring levels of the subsea tunnel are divided into levels A, B, C and D from low to high according to the range of monitoring level index. Monitoring levels and measures are determined on the basis of tunnel risk acceptance criteria.

\section{Tab. 4. Classification table of life-cycle monitoring levels of the tunnel}

\begin{tabular}{|c|c|c|c|c|}
\hline Risk level & $\begin{array}{c}\text { Acceptance } \\
\text { criteria }\end{array}$ & $\begin{array}{c}\text { Monitoring } \\
\text { level index }\end{array}$ & $\begin{array}{c}\text { Monitoring } \\
\text { levels }\end{array}$ & Monitoring measures \\
\hline Low level & Negligible & $1-2$ & Level A & $\begin{array}{c}\text { This level has low risks, } \\
\text { monitoring can be } \\
\text { neglected }\end{array}$ \\
\hline $\begin{array}{c}\text { Moderate } \\
\text { level }\end{array}$ & Acceptable & $3-6$ & Level B & $\begin{array}{c}\text { This level has moderate } \\
\text { risks, monitoring can } \\
\text { be carried out only in } \\
\text { construction period }\end{array}$ \\
\hline High level & Not expected & $8-12$ & Level C & $\begin{array}{c}\text { This level has high } \\
\text { risks, monitoring needs } \\
\text { to be strengthened, } \\
\text { monitoring during } \\
\text { construction period } \\
\text { must be carried out, } \\
\text { monitoring during } \\
\text { operation period may } \\
\text { assist }\end{array}$ \\
\hline high level & Unacceptable & $15-25$ & Level D & $\begin{array}{c}\text { This level has extremely } \\
\text { high risks, monitoring } \\
\text { must be strengthened, } \\
\text { life-cycle monitoring } \\
\text { shall be carried out }\end{array}$ \\
\hline
\end{tabular}

Tab. 3. Risk level standard

\begin{tabular}{|c|c|c|c|c|c|c|}
\hline \multicolumn{2}{|c|}{$\begin{array}{c}\text { Consequence level } \\
\text { Probability level } \\
1\end{array}$} & Slight & Great & Serious & Very serious & Disastrous \\
\cline { 3 - 7 } & 2 & 3 & 4 & 5 & Extremely high level \\
\hline Very likely & 5 & High level & High level & Extremely high level & Extremely high level & Extremely high level \\
\hline Probably & 4 & Moderate level & High level & High level & Extremely high level & Extremely high level \\
\hline Accidentally & 3 & Moderate level & Moderate level & High level & High level & High level \\
\hline Impossible & 2 & Low level & Moderate level & Moderate level & High level & High level \\
\hline Very unlikely & 1 & Low level & Low level & Moderate level & Moderate level & \\
\hline
\end{tabular}




\section{VARIATION FORMS AND MONITORING LEVELS OF THE SUBSEA TUNNEL}

Through an investigation and analysis of the variations occurred in Xiang'an seabed construction stage, collapse, large deformation, cracking and water leakage, reinforcement and concrete corrosion at primary support, hydraulic pressure increase and other variation phenomena appeared in the construction process of tunnel, wherein some variation forms directly affect the safety of the tunnel in the short term of construction stage, while some will affect the safety over a long period of operation. Thus, the tunnel variation forms possibly corresponding to each monitoring level are shown in Table. 5.

Tab. 5. Variation forms of each monitoring level segment of the tunnel

\begin{tabular}{|c|l|c|}
\hline $\begin{array}{c}\text { Monitoring } \\
\text { levels }\end{array}$ & \multicolumn{1}{|c|}{ Variation forms } & $\begin{array}{c}\text { Variation } \\
\text { consequences }\end{array}$ \\
\hline A & $\begin{array}{l}\text { Water leakage, reinforcement } \\
\text { corrosion, shotcrete corrosion }\end{array}$ & Slight \\
\hline B & $\begin{array}{l}\text { Collapse, cracking and water leakage } \\
\text { at primary support, steel arch } \\
\text { corrosion, concrete corrosion }\end{array}$ & $\begin{array}{c}\text { Moderate or } \\
\text { serious }\end{array}$ \\
\hline C & $\begin{array}{l}\text { Large deformation, collapse, cracking } \\
\text { and water leakage at primary support, } \\
\text { steel arch corrosion, concrete } \\
\text { corrosion, vertical uneven settlement }\end{array}$ & Very serious \\
\hline D & $\begin{array}{l}\text { Large deformation, collapse, cracking } \\
\text { and water leakage at primary support, } \\
\text { water pressure increase, steel arch } \\
\text { corrosion, } \\
\text { concrete corrosion, vertical uneven } \\
\text { settlement }\end{array}$ & Disastrous \\
\hline
\end{tabular}

\section{CONCLUSIONS}

In this paper, China's Xiang'an Xiamen subsea tunnel is taken as the research object, and the following main results are obtained through classification of the life-cycle safety monitoring levels of the subsea tunnel:

1) Classification of the life-cycle safety monitoring levels of the subsea tunnel is made on the basis of risk assessment theory and risk level management benchmark, the lifecycle monitoring levels of the subsea tunnel are divided into levels $\mathrm{A}, \mathrm{B}, \mathrm{C}$ and $\mathrm{D}$ from low to high according to the range of monitoring level index;

2) Through an investigation of the surrounding rock of Xiang'an subsea tunnel and variations of its primary support as well as an analysis of the monitoring data, we found that the main variation forms of the subsea tunnel are large deformation, collapse, cracking and water leakage of primary support structure, water pressure increase, steel arch corrosion, concrete corrosion, etc., and the possible variation forms, influence factors and indexes of structure safety in each monitoring level segment are further determined.
3) By applying the research findings into life-cycle monitoring system of subsea tunnels, we can solve the assessment and segmenting issue of life-cycle safety monitoring levels of subsea tunnels, thus providing a basis for determining lifecycle monitoring projects and their layout of measuring points in the future.

\section{ACKNOWLEDGEMENTS}

This work was supported by the national natural science foundation of china (51208069), and the State Key Laboratory of Geohazard Prevention and Geoenvironment Protection (SKLGP2012Z005, SKLGP2016Z010).

\section{REFERENCES}

1. American Institute of Architects.: Life Cycle Cost Analysis: A Guide for Architects. The USA: American Library Association, 1977.

2. Cheung, M. S., Naumoski, N.: The first smart long-span bridge in Canada-health monitoring of the Confederation Bridge. In: Mufti AA, editor.: Proceedings of the 1st international work-shop on structural health monitoring of innovative civil engineering structures. Winnipeg: ISIS Canada Corporation, pp. 31-44, 2002.

3. Frangopol, D. M.: Life-cycle cost analysis for bridge, Bridge Safety and Reliability. ASCE Reston: VA, pp. 210-236, 1999.

4. Flanagan, R.: Life Cycle Costing - the Issues Involved. Proceeding of Third International Symposium on Building Economics, Ottawa, Paper A 1, 1984.

5. A.S. Rakhra.: Buildings and Life-Cycle Costing. Canadian Building Digests-212, Originally published July, 1980.

6. Lee, Y. J., Chang, L. M.: Rehabilitation decision analysis and life-cycle costing of the infrastructure system. Construction Research, no. 82, pp. 1-6, 2003.

7. Andersen, E. Y., Pedersen, L.: Structural monitoring of the Great Belt East Bridge. In: Krokebogr J, editor. Strait crossings 94. Rotterdam: Balkema, pp. 189-95, 1994.

8. Fujino, Y., Abe, M. .: Structural health monitoring-current status and future. In: Boller C, Staszewski WJ, editors. Proceedings of the 2nd European workshop on structural health monitoring. Lancaster (PA): DEStech, pp. 3-10, 2004.

9. Myrvoll, F., Aarnes, K. A., Larssen, R. M.: Full scale measurements for design verification of bridges. In: Proceedings of the 18th international modal analytical conference. Bethel (CT): Society for Experimental Mechanics, pp. 827-35, 2000. 
10. Wu, Z. S.: Structural health monitoring and intelligent infrastructures in Japan. In: Wu ZS, Abe M, editors.: Structural health monitoring and intelligent infrastructure. Lisse: Balkema, pp. 153-67, 2003.

11. Wang, M. L.: State-of-the-art applications in health monitoring. In: Invited presentation to workshop on basics of structural health monitoring and optical sensing technologies in civil engineering. Taiwan: National Central University, pp. 13-4, 2004.

12. Cheung, M. S., Tadros, G. S., Brown, T., Dilge, W. H., Ghali, A., Lau, D. T.: Field monitoring and research on performance of the Confederation Bridge. Canadian Journal of Civil Engineering, Vol. 24, no. 6, pp. 951-62, 1997.

13. Barrish Jr R. A, Grimmelsman K. A, Aktan A. E., Instrumented monitoring of the Commodore Barry Bridge. In: Aktan AE, Gosselin SR, editors. Nondestructive evaluation of highways, utilities, and pipelines IV. Bellingham (WA): The International Society for Optical Engineering, pp. 112-26, 2000.

14. Sumitro, S., Matsui, Y., Kono, M., Okamoto, T.: Long span bridge health monitoring system in Japan. In: Chase SB, Aktan AE, editors. Health monitoring and management of civil in frastructure systems. Bellingham (WA): The International Society for Optical Engineering, pp. 517-24, 2001. Kim, S., Chang, S. P., Lee, J.: Autonomous on-line health monitoring system for a cable-stayed bridge. In: Balageas DL, editor. Proceedings of the 1st European workshop on structural health monitoring. Lancaster (PA): DEStech, pp. 1254-61, 2002.

15. Lau, C. K., Mak, W. P. N, Wong, K. Y., Chan, W. Y. K., Man, K. L. D.: Structural health monitoring of three cablesupported bridges in Hong Kong. In: Chang FK, editor. Structural health monitoring. Lancaster (PA): Technomic, pp. 450-60, 1999.

16. He, X. H., Chen, Z. Q., Huang, F. L.: Preliminary studies on safety monitoring and state assessment for Nanjing Yangtse River Bridge. Journal of vibration and shock, Vol. 22, no. 1, pp.75-78, 2003.

17. Su, M. B, Du, Y. L., Sun, B.C., Chen, B. P.: Study on the long-term health monitoring and alarming system for the Wuhu Yangtze River Bridge. Journal of the China Railway Society, Vol. 29, no. 2, pp. 71-76, 2007.

18. A Code of Practice for Risk Management of Tunnel Works, Prepared by the International Tunnelling Insurance Group in Association with Munich Re Group, 2005

\section{CONTACT WITH THE AUTHORS}

\section{Xiaoqiang XUE}

$$
\begin{gathered}
\text { e-mail: lujunfu@126.com } \\
\text { tel.: +86-13438190478 }
\end{gathered}
$$

State Key Laboratory of Geohazard Prevention and Geoenvironment Protection Chengdu University of Technology Sichuan Chengdu, 610059

\section{China}

